Agro-Science Journal of Tropical Agriculture, Food, Environment and Extension Volume 17 Number 2 (May 2018) pp. $1-8$

ISSN 1119-7455

\title{
EVALUATION OF THE NUTRITIONAL AND FUNCTIONAL PROPERTIES OF TALIA MADE FROM WHEAT/SORGHUM FLOUR BLENDS
}

\author{
Ibrahim, D.G. and Ani, J.C. \\ Department of Food Science and Technology.University of Nigeria Nsukka \\ Corresponding author's email: idoris170@gmail.com
}

\begin{abstract}
Semolina (Triticum durum) was blended with sorghum (Sorghum bicolor) flour at different ratios of 100:0, 90:10, 80:20, 70:30, 60:40, and 50:50. The blends were used to produce Talia, a local noodle of the northern origin, usually a thin strips of dough locally made from semolina using manual cold extrusion and drying. The flour blends were subjected to functional properties analysis, while the Talia produced were analysed for proximate composition and cooking test. Result showed increase $(7.33 \%-12.33 \%)$ in water absorption capacity and decrease $(52 \%-45 \%)$ in swelling capacity as sorghum level increases in the flour blends. Talia made from the flour composites showed significant $(p<0.05)$ increases in protein content $(10.10 \%-10.50 \%)$ and crude fibre $(1.50 \%-$ $1.87 \%)$, while decreases were observed in moisture contents $(9.86 \%-8.00 \%)$. Significant $(p<0.05)$ increases in cooking loss $(1.37 \%-8.2 \%)$, total organic matter (1.26 - 2.84) and reduced expansion ratio (3.0 - 2.0) relative to control were also observed in the cooked Talia. Flour blend with $30 \%$ sorghum addition showed low water absorption (10.0\%), high swelling capacity (50.3\%), low cooking loss $(6.19 \%)$ and total organic matter value $(<2.1)$, therefore, could produce acceptable Talia.
\end{abstract}

\section{INTRODUCTION}

Talia is a Hausa name for local noodles. It consists of thin strips of dough locally made from durum wheat using manual cold extrusion and drying. Sorghum, a principal source of energy, protein, vitamins and minerals is less utilized among the cereals cultivated in Nigeria, The protein content is comparable to that of wheat and maize and it is tannin free (NRC, 1996). Sorghum contains $100 \%$ amylopectin and since it is glutein free makes it a good substitute for wheat flour (Miche et al., 1977). Composite flour technology holds a great future for developing countries (Dendy, 1992). Thus, the use of composite flour has been encouraged since it reduces the importation of wheat, lowers cost of production, encourages production and use of indigenous cereals (Omeire and Ohambelle, 2010). The use of locally available inexpensive cereal like sorghum that substitute a part of wheat flour without adversely affecting the acceptability of the product will be a welcome development. Partial substitution of wheat flour with sorghum flour will increase the overall nutrients (Adebowale et al., 2012), encourage the agricultural sector, increase the Talia pasta variety, and reduce dependence on semolina for production of pasta as well as lower production cost. This work therefore seeks to evaluate the nutritional and functional properties of the flour blends and to determine the optimal level of semolina substitution with sorghum in formulating good quality Talia using water absorption capacity, cooking loss, total organic matter and swelling capacity.

\section{MATERIALS AND METHODS}

The raw materials used in this study were white sorghum (Sorghum bicolor) and semolina (Triticum durum). Sorghum grains (white variety) were purchased from Ibi market in Ibi Local Government Area in Taraba State, Nigeria. Semolina was purchase from Oggige market Nsukka in EnuguState, Nigeria.

Preparation of sorghum flour

The sorghum grains $(5 \mathrm{~kg})$ were sorted cleaned, dehulled, winnowed, and milled (attrition mill, De-Demark super Gx 160.55), sieved $(600 \mu \mathrm{m})$ and heat sealed in polyethylene pouches and stored until used for analysis and product formulation.

Formulation of composite flours

Semolina and sorghum composite flours were formulated as shown in Table 1 


\section{Production of talia pasta}

Talia samples were produce using the method described by Kent (1983) (Figure 1). Each flour blend was made into a stiff dough using $70-90 \mathrm{ml}$ of water per $100 \mathrm{~g}$ flour blend. The volume of water used for each samples are as follows: W and WS1 $(70 \mathrm{ml}), \mathrm{WS} 2$ and WS3 $(80 \mathrm{ml})$, WS4 and WS5 $(90 \mathrm{ml})$. After mixing, the dough was allowed to rest for 10 minutes and then kneaded until it is malleable, sheeted with a manual wooden roller and cut into strands using the pasta cutting machine (Imperia titania pasta cutting machine, China). The long strands were cut uniformly into the desired length $(15 \mathrm{~cm})$ before drying. The Talia strands were put in clean aluminum trays and oven dried (Gallenkamp, England) at $80^{\circ} \mathrm{C}$ for one hour to a moisture content of $18 \%$. The samples were allowed to rest in the oven for 4 hours after the initial drying. This was to allow moisture equilibration between the inner core and the outer surface of the product. Further drying was done at $60^{\circ} \mathrm{C}$ for six hours to bring the Talia to moisture content of $12 \%$. The dried Talia samples were sealed in polyethylene bags and stored at ambient temperatureuntil used for analysis.

\section{Determination of proximate composition}

Moisture, crude protein, total ash, total fat, crude fibre and carbohydrate contents were determined according to the methods of AOAC (2010)

\section{Determination of functional properties of flour composites}

Determination of Water Absorption Capacity

The method of Beuchart (1977) was used to determine the water absorption capacity. Exactly $1 \mathrm{~g}$ of the sample was weighed into a test tube to which $10 \mathrm{ml}$ of distilled water was added. The content of the test tube was mixed thoroughly and allowed to stand for $10 \mathrm{~min}$. The slurry was centrifuged (800-1 lower speed centrifugal machine) at 5,000 rpm for $30 \mathrm{~min}$. The supernatant was decanted into a $10 \mathrm{ml}$ measuring cylinder and the volume was measured. The difference in the volume of the water originally added $(10 \mathrm{ml})$ and the volume of the supernatant decanted was taken as the amount of water absorbed by the sample. Percentage water absorbed was calculated with the expression

\section{$\%$ Waterabsorptioncapacity $=$ $\frac{\text { Differenceinvolumeofwaterafterabsorption }}{\text { Originalvolumeofwater }} \times \frac{100}{1}$}

Soluble Solids Determination

The method described by Mestres et al. (1988) was adopted for the determination of soluble solids. Two grams (W2) each of the composite flours was weighed into a test tube containing $10 \mathrm{ml}$ distilled water. The test tube was shaken vigorously for even dispersion of the flour in the water. The mixture was centrifuged (800-1 lower speed centrifugal machine) at 7,500 rpm for $10 \mathrm{~min}$. The supernatant was decanted into a previously weighed Petri dish (W1), evaporated, and dried at $1300 \mathrm{C}$ to constant weight (W3). The soluble solid was calculated by weight difference and expressed as a percentage of the sample weight used.

$$
\% \text { Solublesolids }=\frac{W_{3}-W_{1}}{W_{2}} \times \frac{100}{1}
$$

where:

W1 - weight of empty petri dish

W2 - weight of sample

W3 - weight of petri dish plus dry supernatant Swelling Capacity Determination. The method described by Leach et al. (1959) was used in the determination of swelling capacity. Exactly $10 \mathrm{ml}$ of distilled water was put into three graduated centrifuge tubes and $1 \mathrm{~g}$ of sample was added. The tubes were thoroughly stirred and centrifuged (800-1 lower speed centrifugal machine) at $1000 \mathrm{rpm}$ for $5 \mathrm{~min}$. The volumes of the centrifuged samples in the tubes were read off immediately. The tubes were subjected to heating in a water bath set at $600 \mathrm{C}$ for 1 hour with constant stirring. The heated suspension was centrifuged (800-1 lower speed centrifugal machine) at $1000 \mathrm{rpm}$ for $15 \mathrm{~min}$. The volumes of the sample in the tubes were read. The swelling capacity of the sample was calculated thus:

$$
\begin{aligned}
& \% \text { Swelling capacity }= \\
& \text { Vol.ofsuspensionafter Vol.ofsuspensionafter } \\
& \frac{\text { heatingandcentrifuging }{ }^{-}{ }^{-} \text {Ventrifugingbeforeheating }}{1 g} \times \frac{100}{1}
\end{aligned}
$$

Water absorption index (WAI) Determination The water absorption index of the flour samples was determined by the method of Mercier and Feilliet (1975). Two grams of flour sample was weighed into a porcelain dish and $10 \mathrm{ml}$ of water was added. The porcelain dish was heated in a water bath at $1000 \mathrm{C}$ for $30 \mathrm{~min}$. The resultant slurry was allowed to stand for $10 \mathrm{~min}$ and the supernatant was decanted. The gel was weighed. The water absorption index was calculated, thus:

where;

$$
W A I=\frac{W_{2}}{W_{1}}
$$

W1 - Weight of dry sample

W2 - Weight of gel

WAI -Gram gel obtained per gram of dry sample Swelling index (SI) Determination 
Swelling index of flour composites were determined using the method described by Mestres et al. (1988). Two grams of sample was weighed into a porcelain dish and $10 \mathrm{ml}$ of water was added. The porcelain dish was heated for 30 minutes in a water bath at 1000C. The cooked sample was drained and rapidly weighed (W1). The cooked product was dried to constant weight (W2). Swelling index was calculated thus:

$$
\% \text { Swellingindex }(S I)=\frac{W_{1}-W_{2}}{W_{2}} \times \frac{100}{1}
$$

where

W1-Weight of cooked sample

W2 -Weight of cooked dried sample

Water solubility index (WSI) Determination

The method described by Mercier and Feilliet (1975) was used for the determination of water solubility index. Two grams of the sample was weighed into a porcelain dish and $10 \mathrm{ml}$ of water was added. The porcelain dish was heated for $30 \mathrm{~min}$ in a water bath at $1000 \mathrm{C}$. The gel formed was separated from the solution. The solution was centrifuged and supernatant was decanted. The supernatant was dried to constant weight and the water solubility index was calculated thus:

where;

$$
\% W S I=\frac{W_{1}}{W_{2}} x \frac{100}{1}
$$

W1-Weight of dry sample

W2 -Weight of dry matter

WS -Water solubility index as percent dry sample

\section{Cooking test of Talia \\ Cooking test determination}

The method described by Mestres et al. (1988) was employed. Distilled water $(150 \mathrm{ml})$ was heated under reflux in a $250 \mathrm{ml}$ beaker. As the water boiled, $5 \mathrm{~g}$ cut talia ( $2 \mathrm{~cm}$ long) was added. Optimum cooking time was determined by the crushing test (Das and Chattora, 1988). After each minute of cooking, a portion of talia was removed and squeezed between two transparent plates. On complete cooking; no white core remained when the noodles were squeezed between the plates. The tested talia were discarded. The time taken for complete disappearance of white core was considered to be the cooking time. Cooking continued $1 \mathrm{~min}$ more than the optimum cooking time. The sample was drained and left for $5 \mathrm{~min}$ and rapidly weighed (W1). The cooked samples were dried in an oven at $1300 \mathrm{C}$ to constant weight (W2). Cooking water was centrifuged (800-1 lower speed centrifugal machine) at $7,500 \mathrm{rpm}$ for $10 \mathrm{mins}$. The weight of the dry matter content of the sediment and supernatant (W3) and (W4) respectively, were determined by heating $5 \mathrm{ml}$ of both sediment and supernatant for 2 hours at 1300C. Then the dried residue was weighed. Total cooking losses, which include solid losses, and soluble losses during cooking were calculated with the expression

$$
\begin{aligned}
& \% \text { Solidloss }\left(S L_{1}, \%\right)=\frac{W_{3} \times 100}{5} \times D M \\
& \% \text { Solubleloss }\left(S L_{2}, \%\right)=\frac{W_{4} \times 100}{5} \times D M \\
& \text { Total cooking loss }(\mathrm{TCL}, \%)=\mathrm{SL} 1+\mathrm{SL} 2 \\
& \mathrm{DM}=\text { dry matter ratio of crude sample }
\end{aligned}
$$

\section{Expansion ratio determination}

The radial expansion of the pasta talia was determined by measuring the diameter of the raw and cooked talia with a pair of venier calipers and expressed as the ratio of the cross section of the raw talia rod to that of the cooked talia rod (Mercier and Feilliet, 1975)

$$
\begin{aligned}
& \text { Expansionratio } \\
& =\frac{\text { Cross }- \text { sectionofrawtaliarod }}{\text { Cross }- \text { sectionforthecookedtaliarod }}
\end{aligned}
$$

Total Organic Matter (T.O.M) Determination Total organic matter of the talia was determined by the method described by D'Egidio et al. (1982). The method was based on washing the substances coating the surface of $100 \mathrm{~g}$ of cooked talia with $500 \mathrm{ml}$ of water at room temperature for $12 \mathrm{~min}$. During the 12 minutes washing, the product was stirred three times every $4 \mathrm{~min}$. The talia was taken out and the washing water was analyzed for total organic matter. Exactly $5 \mathrm{ml}$ of the well stirred washing water suspension was pipetted into a $600 \mathrm{ml}$ beaker and was evaporated at $800 \mathrm{C}$. After complete evaporation, further heating was avoided. Exactly $10 \mathrm{ml}$ of $\mathrm{K} 2 \mathrm{Cr} 2 \mathrm{O} 7$ was added from a burette to wet the residue completely. Then $20 \mathrm{ml}$ of $90 \%$ solution of $\mathrm{H} 2 \mathrm{SO} 4$ was pipetted into the beaker, mixed for $1 \mathrm{~min}$ and allowed to stand for $30 \mathrm{~min}$. The mixture was diluted with $200 \mathrm{ml}$ of distilled water and $\mathrm{K} 2 \mathrm{Cr} 2 \mathrm{O} 7$ was titrated with $0.5 \mathrm{~N} \mathrm{Fe}$ (NH4) 2 (SO4) 2. Diphenylamine (C6H5) 2 $\mathrm{NH}(0.5 \%)$ in Conc. H2SO4 indicator was used. The end point of the titration was indicated by a change of color from violet to green. Result was expressed as gram of starch obtained from $100 \mathrm{~g}$ talia as follows.

$$
\begin{aligned}
& \text { T. O.M. } \\
& =(B-S) \frac{(20)}{B} \times 3.75 \times 100 \times 0.9 \times 1.0283
\end{aligned}
$$


Table 1: Formulation of semolina/sorghum flour blends

\begin{tabular}{lllc}
\hline Flour blends & Wheat $(\mathrm{g})$ & Sorghum $(\mathrm{g})$ & Total $(\mathrm{g})$ \\
\hline W & 100 & 0 & 100 \\
WS1 & 90 & 10 & 100 \\
WS2 & 80 & 20 & 100 \\
WS3 & 70 & 30 & 100 \\
WS4 & 60 & 40 & 100 \\
WS5 & 50 & 50 & 100 \\
W=Semolina & & &
\end{tabular}

S-Sorghum W-Semolina

where:

$\mathrm{B}-\mathrm{ml}$ of $0.5 \mathrm{~N} \mathrm{Fe}(\mathrm{NH} 4) 2$ (SO4)2 used as the blank $\mathrm{S}-\mathrm{ml}$ of $0.5 \mathrm{~N}$ Fe (NH4)2 (SO4)2 Used for the sample 20-Theoretical amount $(\mathrm{ml})$ of $\mathrm{Fe}$ (NH4)2(SO4)2 equivalent to $10 \mathrm{ml}$ of $\mathrm{K} 2 \mathrm{Cr} 2 \mathrm{O} 73.75-\mathrm{mg}$ of glucose equivalent to $1 \mathrm{ml}$ of $0.5 \mathrm{~N} \mathrm{Fe}$ (NH4) 2(SO4)2 100 -Dilution factor 0.9-Factor for conversion of glucose into starch 1.0283 - Correction factor for incomplete digestion. Values will be given as g starch/100g talia T.O.M Values $<1.4$ - very good quality talia 1.4-2.1 - good quality talia $>2.1$ - Low quality talia

\section{Statistical analysis}

Complete randomized design (CRD) was used to design the work.Data obtained from the proximate and functional properties analysis of the raw materials were analyzed using the students T-test, while data obtained from the proximate and functional properties of flour blends and cooking test of Talia were recorded in triplicate and subjected to statistical analysis of variance (ANOVA), mean separation was carried out using least significant different (LSD) at 5\% level of significance.

\section{RESULTS AND DISCUSSIONS}

The results of the proximate composition of semolina and sorghum flours are shown in Table 2. Significant difference $(p<0.05)$ was not observed in the moisture, ash, fat, and crude fibre contents of semolina and sorghum flours. This showed that semolina and sorghum flours have comparable proximate composition as earlier noted by NRC, (1996). The moisture content of the flour samples fall within the $10 \%$ moisture level recommended for safe keeping of flour samples (SON, 2007) and also suitable for Talia keeping quality. The carbohydrate and protein contents of the flour samples were significantly different $(p>0.05)$ from each other, sorghum having lower carbohydrate content and slightly higher protein content than semolina. Although the protein content of these flours is too low for a high quality Talia and therefore need to be improved by adding protein from a legume source.
The results of functional properties of the flour blends are presented in Table 3

The flour samples of semolina and sorghum showed significant differences $(\mathrm{p}<0.05)$ in all the functional properties determined in this study. Sorghum flour recorded higher values in water absorption capacity (18.0\%), soluble solids $(4.0 \%)$ and water solubility index $(5.5 \%)$ than semolina. This could be attributed to the presence of amylopectin in sorghum which is readily water soluble (Miche et al., 1977). High water absorption capacity is not desirable in Talia as this could make it soft and brittle. Semolina showed higher swelling capacity $(52.0 \%)$, water absorption index $(8.04 \%)$ and swelling index $(96.8 \%)$ than sorghum flour. This could be due to the presence of gluten in semolina which has the ability to swell and form gel. High swelling capacity is a significant index in Talia as it aids yield. The $\mathrm{pH}$ of the flours differ significantly $(\mathrm{p}<0.05)$ and are within the range that can inhibit microbial growth (Faubion et al., 1982).

Composite flour of semolina/sorghum
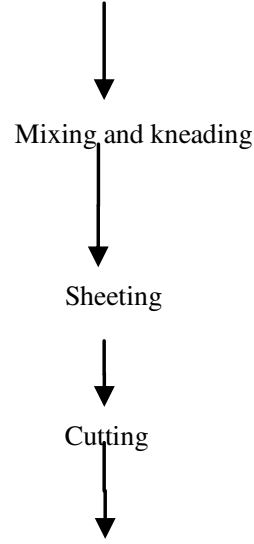

Pre-drying (800C, 1 hour, 18\% MC)

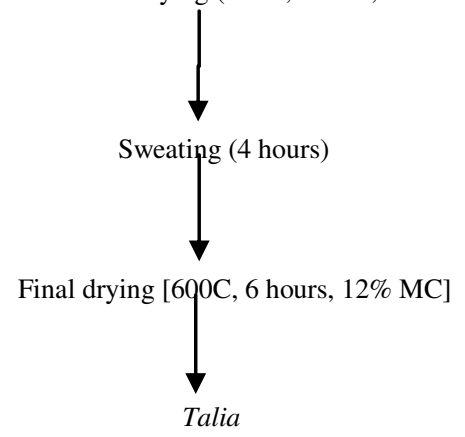

Fig.1: Flow diagram for Talia Production (Source Kent (1983)) 
Table 2: Proximate composition of semolina and sorghum flours

\begin{tabular}{lllllll}
\hline Sample & Components & & & & \\
\hline & Moisture & Ash & Fat & Crude fibre & Crude Protein & Carbohydrates \\
Semolina & $10.00 \mathrm{a} \pm 0.5$ & $1.00 \mathrm{a} \pm 0.0$ & $2.00 \mathrm{a} \pm 0.0$ & $1.30 \mathrm{a} \pm 0.1$ & $10.10 \mathrm{~b} \pm 0.3$ & $75.60 \mathrm{a} \pm 0.26$ \\
Sorghum & $9.50 \mathrm{a} \pm 0.5$ & $1.50 \mathrm{a} \pm 0.5$ & $2.50 \mathrm{a} \pm 0.5$ & $1.70 \mathrm{a} \pm 0.1$ & $11.60 \mathrm{a} \pm 0.4$ & $73.20 \mathrm{~b} \pm 0.26$ \\
\hline
\end{tabular}

Values are means of triplicate determinations \pm standard deviation, means within the same column with the same superscript are not significantly different $(\mathrm{p}>0.05)$.

Table 3: Results of functional properties of semolina and sorghum flours

\begin{tabular}{lll}
\hline Functional Properties & Semolina & Sorghum \\
\hline Water absorption capacity \% & $7.33 \mathrm{~b} \pm 0.58$ & $18.00 \mathrm{a} \pm 0.1$ \\
Soluble solids \% & $2.50 \mathrm{~b} \pm 0.1$ & $4.00 \mathrm{a} \pm 0.01$ \\
Swelling capacity \% & $52.00 \mathrm{a} \pm 0.5$ & $44.00 \mathrm{~b} \pm 0.5$ \\
Water Absorption index gg-1 & $8.04 \mathrm{a} \pm 0.02$ & $4.54 \mathrm{~b} \pm 0.06$ \\
Water solubility index gg-1 & $2.50 \mathrm{~b} \pm 0.05$ & $5.50 \mathrm{a} \pm 0.05$ \\
$\mathrm{pH}$ & $5.32 \mathrm{~b} \pm 0.01$ & $5.41 \mathrm{a} \pm 0.01$ \\
\hline Values are means of triplicate determinations \pm standard deviation. Means within the same row with different superscript are \\
significantly different $(\mathrm{p}<0.05)$.
\end{tabular}

The results of proximate composition of Talia produced from semolina/sorghum flour composites are shown in Table 4.

Result showed no significant differences ( $\mathrm{p}>$ 0.05 ) in moisture content of samples $\mathrm{W}$ and WS1 and also WS4 and WS5. Although decrease in moisture content was observed as the level of sorghum substitution increased. This could be attributed to the increased hydrophilic property of fibre in sorghum as it increases in the composite. This low moisture content predicts good keeping quality of the Talia (Nnam, 2002). Moisture content above $15 \%$ will cause mould to grow (Douglas and Mathew, 1982). Significance ( $<$ 0.05) in fat content was observed between WS3, WS4, WS5 and W (the control). Fat content increased as sorghum levels increased, this is due to the higher fat content of sorghum (Table 2). Increases were observed in all the parameters as sorghum levels increases in the flour blends. But significant differences ( $\mathrm{p}<$ 0.05 ) in ash content were seen in samples WS1 and WS2, WS3 and WS4. All the samples differ $(p<0.05)$ from the control in crude fibre but WS2, WS3 and WS4 are similar ( $p>0.05)$ as were also seen in their water absorption capacity (Table 5) this showed that their water holding capacity will be the same $(p>0.05)$. Protein contents of samples WS3 and WS4 differ significantly $(\mathrm{p}<0.05)$ as also reflected in their expansion ratio (Table 6). Generally, the fat, ash, crude fibre and protein contents of all the samples increased as the level of sorghum increased in the flour blends, except for moisture and carbohydrates contents that decreased. This showed that composites of semolina and sorghum could increase the ash, fat, protein and fibre contents and decrease the moisture and carbohydrates content of Talia (Table 4). This observation agrees with the findings of Adebowale et al. (2012) who reported increases in protein, fat, crude fibre and ash contents of biscuit produced from wheat/sorghum composite flours.

The result of functional properties of semolina/sorghum flour composites is presented in Table 5.

The water absorption capacity of the samples increased from $7.33 \%$ to $12.33 \%$ as the level of sorghum flour increased in the blends. This increase in water absorption capacity could be attributed to the predominance of amylopectin in sorghum which was able to imbibe much water. Sample WS5 had higher water absorption capacity and is significantly different $(\mathrm{p}<0.05)$ from the other samples because high water absorption capacity makes the product soft and brittle. Increases were observed in both soluble solids $(2.5 \%-3.5 \%)$ and water solubility index (2.5gg-1 - 5.0gg-1) of the flour blends as the level of sorghum substitution increased. This increase could be due to the increase in the amylopectin as sorghum increases in the blends. Amylopectin is readily soluble in water which leads to the increase in solubility of the flour blends. Samples WS1, WS2 and WS3 showed significant differences $(\mathrm{p}<0.05)$ among each other in soluble solids, while samples WS1 and WS2 were not significantly different $(p>0.05)$ in water solubility index. High soluble solids and water solubility index predicts high cooking losses of the product (Table 6). There are significant differences $(\mathrm{p}<0.05)$ in swelling capacity among samples WS3, WS4 and WS5, while all the samples differed significantly ( $\mathrm{p}$ $<0.05)$ in swelling index. Decreases were observed in both swelling capacity $(52.0 \%$ $45.4 \%)$ and swelling index $(96.8 \mathrm{gg}-1-72.0 \mathrm{gg}$ 1) of the flour blends as the level of sorghum increased. These decreases were attributed to the decrease of gluten in the blends. High 
swelling capacity and swelling index increase expansion of Talia and have been reported as part of the criteria for good quality pasta product (Achinewhu et al., 1998). Samples WS1 and WS2 were similar $(\mathrm{p}>0.05)$ in water absorption index compared to other samples. Decreases in the water absorption index of the flour blends were observed as the level of sorghum increased. This could be due probably to the decrease in gluten content of the flour blends. The lower the gluten content, the lower the gelling power of the flour blends. This means that higher substitution of semolina with sorghum will affect the swelling or expansion of the Talia. Therefore, samples with lower sorghum substitution were preferred for Talia production.

\section{The result of the cooking test of Talia produced from semolina/sorghum composite flours is shown in Table 6.}

Significant differences $(\mathrm{p}<0.05)$ were observed in expansion ratio among samples. Expansion ratio decreased $(3-2)$ as the sorghum levels increased in the flour blend due probably to the decrease in gluten content as the level of semolina decreased, thereby resulting to poor product yield. There was no significant difference $(\mathrm{p}>0.05)$ among samples in cooking time. Nevertheless the decrease (8 - 5 minutes) observed in cooking time as sorghum levels increases was due probably to amylopectin predominance in sorghum which is readily water soluble. Samples showed significant differences ( $\mathrm{p}<$ $0.05)$ among each other in cooking losses. Sample WS5 showed higher cooking loss $(8.20 \%)$ due probably to higher level of starch leaching, decrease in gluten and amylose as well as increase in amylopectin content of the flour blends and also the high soluble solids of sorghum (Table 2). However, according to Galvez and Ware (1994), solid loss of less than $9 \%$ is acceptable in pasta production; this means that all the samples showed cooking losses that are within acceptable range $(1.37 \%$ to $8.2 \%$ ).All the samples differed significantly $(\mathrm{p}<0.05)$ in total organic matter $($ TOM) value. Sample WS4 and WS5 had TOM values higher than the standard value (2.1) (D' Egidio et al., 1982) and were adjudged to be of low quality Talia. This is because higher materials deposits were found on the Talia surface which resulted to a high TOM value. High materials deposit makes Talia sticky resulting to poor quality (D’ Egidio et al., 1982).

Table 4: Proximate composition (\%) of Talia produced from semolina/sorghum composite flours

\begin{tabular}{lllllll}
\hline Samples & Moisture & Fat & Ash & Fibre & Protein & Carbohydrates \\
\hline W & $9.86 \mathrm{a} \pm 0.01$ & $1.68 \mathrm{~d} \pm 0.10$ & $1.00 \mathrm{c} \pm 0.01$ & $1.50 \mathrm{~d} \pm 0.10$ & $10.10 \mathrm{~d} \pm 0.10$ & $75.86 \mathrm{~d} \pm 0.01$ \\
WS1 & $9.85 \mathrm{a} \pm 0.01$ & $1.70 \mathrm{~d} \pm 0.05$ & $1.00 \mathrm{c} \pm 0.00$ & $1.65 \mathrm{c} \pm 0.01$ & $10.17 \mathrm{~cd} \pm 0.02$ & $75.63 \mathrm{f} \pm 0.01$ \\
WS2 & $9.00 \mathrm{~b} \pm 0.10$ & $1.75 \mathrm{~cd} \pm 0.05$ & $1.50 \mathrm{~b} \pm 0.05$ & $1.75 \mathrm{~b} \pm 0.01$ & $10.25 \mathrm{bc} \pm 0.02$ & $75.75 \mathrm{e} \pm 0.01$ \\
WS3 & $8.50 \mathrm{c} \pm 0.10$ & $1.86 \mathrm{bc} \pm 0.03$ & $1.50 \mathrm{~b} \pm 0.00$ & $1.76 \mathrm{~b} \pm 0.01$ & $10.30 \mathrm{~b} \pm 0.01$ & $76.08 \mathrm{~b} \pm 0.01$ \\
WS4 & $8.00 \mathrm{~d} \pm 0.10$ & $1.90 \mathrm{ab} \pm 0.05$ & $1.61 \mathrm{a} \pm 0.01$ & $1.80 \mathrm{ab} \pm 0.01$ & $10.42 \mathrm{a} \pm 0.01$ & $76.27 \mathrm{a} \pm 0.01$ \\
WS5 & $8.00 \mathrm{~d} \pm 0.17$ & $2.00 \mathrm{a} \pm 0.10$ & $1.65 \mathrm{a} \pm 0.01$ & $1.87 \mathrm{a} \pm 0.01$ & $10.50 \mathrm{a} \pm 0.01$ & $75.98 \mathrm{c} \pm 0.01$ \\
\hline
\end{tabular}

Values are means of triplicate determinations \pm standard deviation. Means within the same column with the same superscript are not significantly different (p>0.05). W - Semolina 100\% WS1 - Semolina 90\%/Sorghum 10\% WS2 - Semolina 80\%/Sorghum

Table 5: Functional properties of Semolina/Sorghum flour composites

\begin{tabular}{lllllll}
\hline Functional properties & $\mathrm{W}$ & $\mathrm{WS}_{1}$ & $\mathrm{WS}_{2}$ & $\mathrm{WS}_{3}$ & $\mathrm{WS}_{4}$ & $\mathrm{WS}^{5}$ \\
\hline Water absorp.capacity (\%) & $7.33 \mathrm{e} \pm 0.58$ & $8.33 \mathrm{de} \pm 0.58$ & $9.33 \mathrm{~cd} \pm 1.0$ & $10.00 \mathrm{bc} \pm 1.0$ & $10.66 \mathrm{~b} \pm 0.58$ & $12.33 \mathrm{a} \pm 1.1$ \\
Soluble solids (\%) & $2.50 \mathrm{c} \pm 0.2$ & $2.50 \mathrm{c} \pm 0.1$ & $3.00 \mathrm{~b} \pm 0.1$ & $3.50 \mathrm{a} \pm 0.1$ & $3.50 \mathrm{a} \pm 0.17$ & $3.50 \mathrm{a} \pm 0.2$ \\
Swelling capacity (\%) & $52.00 \mathrm{a} \pm 1.0$ & $51.60 \mathrm{ab} \pm 0.1$ & $51.00 \mathrm{bc} 0.1$ & $50.30 \mathrm{c} \pm 0.1$ & $49.00 \mathrm{~d} \pm 0.5$ & $45.40 \mathrm{e} \pm 0.1$ \\
Water absorp.index (gg-1) & $8.04 \mathrm{a} \pm 0.01$ & $7.85 \mathrm{~b} \pm 0.01$ & $7.75 \mathrm{~b} \pm 0.01$ & $7.60 \mathrm{c} \pm 0.1$ & $6.50 \mathrm{~d} \pm 0.1$ & $5.80 \mathrm{e} \pm 0.1$ \\
Swelling index (gg-1) & $96.80 \mathrm{a} \pm 0.1$ & $91.70 \mathrm{~b} \pm 0.17$ & $82.90 \mathrm{c} \pm 0.1$ & $82.00 \mathrm{~d} \pm 0.1$ & $75.60 \mathrm{e} \pm 0.1$ & $72.00 \mathrm{f} \pm 0.1$ \\
Water solub. Index (gg-1) & $2.50 \mathrm{e} \pm 0.1$ & $3.50 \mathrm{~d} \pm 0.1$ & $3.50 \mathrm{~d} \pm 0.1$ & $4.00 \mathrm{c} \pm 0.1$ & $4.50 \mathrm{~b} \pm 0.1$ & $5.00 \mathrm{a} \pm 0.1$ \\
pH & $5.32 \mathrm{~d} \pm 0.01$ & $5.45 \mathrm{e} \pm 0.01$ & $5.51 \mathrm{~b} \pm 0.01$ & $5.55 \mathrm{a} \pm 0.02$ & $5.52 \mathrm{ab} \pm 0.01$ & $5.51 \mathrm{~b} \pm 0.02$ \\
\hline
\end{tabular}

Values are means of triplicate determinations \pm standard deviation. Means within the same row with the same superscript are not significantly different ( $\mathrm{p}>0.05$ ). W- Semolina 100\% WS1 - Semolina 90\%/Sorghum 10\% WS2 - Semolina $80 \% /$ Sorghum $20 \%$ WS3 - Semolina 70\%/Sorghum 30\% WS4 - Semolina 60\%/Sorghum 40\% WS5 - Semolina 50\%/Sorghum 50\% $20 \%$ WS3 - Semolina 70\%/Sorghum 30\% WS4 - Semolina 60\%/Sorghum 40\% WS5 - Semolina 50\%/Sorghum 50\% 
Table 6: Cooking test of Talia produced from Semolina/Sorghum composite flours

\begin{tabular}{lllllll}
\hline Functional properties & W & WS1 & WS2 & WS3 & WS4 & WS5 \\
\hline Cooking time (Min) & $8.00 \mathrm{a} \pm 1.0$ & $8.00 \mathrm{a} \pm 1.0$ & $8.00 \mathrm{a} \pm 0.0$ & $7.00 \mathrm{ab} \pm 0.0$ & $7.00 \mathrm{ab} \pm 0.1$ & $6.00 \mathrm{~b} \pm 0.0$ \\
Expansion ratio & $3.00 \mathrm{a} \pm 0.1$ & $2.71 \mathrm{~b} \pm 0.0$ & $2.50 \mathrm{c} \pm 0.0$ & $2.30 \mathrm{~d} \pm 0.1$ & $2.16 \mathrm{e} \pm 0.01$ & $2.00 \mathrm{f} \pm 0.1$ \\
Soluble loss (\%) & $0.70 \mathrm{a} \pm 0.01$ & $0.50 \mathrm{c} \pm 0.01$ & $0.60 \mathrm{~b} \pm 0.01$ & $0.70 \mathrm{a} \pm 0.01$ & $0.50 \mathrm{c} \pm 0.01$ & $0.50 \mathrm{~d} \pm 0.01$ \\
Solid loss (\%) & $0.70 \mathrm{a} \pm 0.01$ & $2.00 \mathrm{~d} \pm 0.01$ & $2.20 \mathrm{~d} \pm 0.02$ & $5.5 \mathrm{c} \pm 0.02$ & $6.10 \mathrm{~b} \pm 0.01$ & $7.80 \mathrm{a} \pm 0.02$ \\
Total cooking loss(\%) & $1.37 \mathrm{f} \pm 0.03$ & $2.49 \mathrm{e} \pm 0.03$ & $2.73 \mathrm{~d} \pm 0.01$ & $6.19 \mathrm{c} \pm 0.01$ & $6.58 \mathrm{~b} \pm 0.02$ & $8.20 \mathrm{a} \pm 0.01$ \\
Total organic matter & $1.26 \mathrm{f} \pm 0.01$ & $1.57 \mathrm{e} \pm 0.01$ & $1.89 \mathrm{~d} \pm 0.01$ & $2.21 \mathrm{c} \pm 0.01$ & $2.52 \mathrm{ab} \pm 0.0$ & $2.84 \mathrm{a} \pm 0.01$ \\
& & & & & 2 & \\
\hline
\end{tabular}

Values are means of triplicate determinations \pm standard deviation. Means within the same row with the same superscript are not significantly different (p>0.05). W- Semolina 100\% WS1 - Semolina 90\%/Sorghum 10\% WS2 - Semolina 80\%/Sorghum 20\% WS3

- Semolina 70\%/Sorghum 30\% WS4 - Semolina 60\%/Sorghum 40\% WS5- Semolina 50\%/Sorghum 50\%

\section{CONCLUSION}

Semolina and sorghum flour showed no significant difference $(p>0.05)$ in proximate composition except in protein and carbohydrate content. The entire flour composite had moisture content lower than $15 \%$ standard recommended for safe keeping of product showing that Talia will have good shelf life. The semolina /sorghum composite increased the fat, crude fibre, ash and protein contents of the product. Low water absorption capacity, cooking losses and high swelling capacity were observed in samples with sorghum substitution up to $30 \%$. Thus, substitution of semolina with sorghum flour up to $30 \%$ could produce acceptable talia.

\section{REFERENCES}

Achinewhu S.C. Baiben I.J. and Ijeoma J.O. (1998). Physiochemical properties and certification of selected cassava cultivars in Rivers State. Plant Food Human Nutrition. 52, 133-140

Adebowale A.A. Adegoke M.T. Sanni S.A. Adegunwa M.O. and Fetuga G.O. (2012). Functional properties and biscuit making potentials of sorghum-wheat flour composite. American Journal of Food Technology, 7, 372-379

AOAC (2010). Association of Official Analytical Chemists.Official Methods of Analysis (18th Ed). Washington DC

Beuchart L.R. (1977). Functional and electrophoretic characteristics of succinylated peanut protein. Journal of Agriculture and Chemistry, 25 (2), 258260

D’EgidioM.G. Stefanis E.D. Fortini S. Galterio G. Nardis S. Sgrulleta D. and Bozzini. (1982). Standardization of working quality analysis in macaroni and pasta product. Cereal Food World, 72 (8), 367-368

Dendy D.A.V. (1992). Composite flourpresent, and the future, a review with special emphasis on the place of composite flour in the semi-arid zones. In: M.I. GomezLR. HouseL.W. Rooney and D.A.V.
Dendy et al. (Eds). Utilization of sorghum and millets (pp 67-73). Patancheru

Douglas J.S. and Mathews R.H (1982). Nutrient content of pasta products. Journal of Food. Science Technology, 27, 178-180

Faubion R.C. Hoseney R.C. and Sieb P.A. (1982). Effect of $\mathrm{pH}$ on pasta quality. Cereal Food World, 27 (5), 212-216

Galvez F.C.F. and Ware G.O. (1994). Process variable, gelatinized Starch and moisture effects in physical properties of Mungbeans noodles. Journal of Food Science, 59 (2), 378-386

Kent N.L (1983). Technology of cereal. (3rd Ed). Pergman Press Ltd. Oxford, England pp149-205

Leach H.W. McCowen L.D. and Schooh T.J. (1959). Structure of the starch granule I. Swelling and Solubility.Cereal Chemistry, 36, 534-539

Mercier C. and Feillet P. (1975). Modification of carbohydrate components by extrusioncooking of cereal product.Cereal Chemistry, 52, 282-297

Mestres C. Colonna P. and Buleon A. (1988). Characteristics of starch network within rice flour noodles and mungbean starch vermicelli. Journal of Food Science, 53 (6), 1809-1811

Miche J.C. Alary R. JeanJean M.F. and Abecassis J. (1977). Potential use of sorghum grains in pasta processing. In: D.A.V. Dendy, (Ed.), Proceeding of $a$ symposium on sorghum and millets for human food (pp 27-35). Londres, Institute des produitstropicaux

Nnam N.M. (2002). Evaluation of complementary foods based on maize, soybean, pawpaw and mango flour blends. Nigerian Journal Nutrition Science. 22(23), 8-18

NRC (1996). Board on Science and Technology for international development (BOSTID) .1Grains (pp 180). National Academy press, Washington D.C. 
Omeire G.C. and Ohambelle F.I. (2010). Production and evaluation of biscuits from composite wheat/defatted cashew nut flours. Nigerian Food Journal 28(2), 401-406
SON (2007). Nigerian Industrial Standard for Pastas (pp1-8). Standard Organization of Nigeria. ICS, 664. 68 